\title{
Sexual health: the Cinderella of reproductive health services
}

\section{Lindsay Edouard}

International Advisory Editor, Port Louis, Mauritius

\section{Correspondence to} Professor Lindsay Edouard; soranae@gmail.com

Received 11 July 2013 Accepted 3 August 2013
To cite: Edouard L. J Fam Plann Reprod Health Care 2013;39:297-299.

\section{SUMMARY}

Twenty-five years ago, articles in this Journal highlighted the lack of resources allocated for family planning services in Britain and also major concerns regarding policies on induced abortion, sexuality and HIV control. Discussions were initiated leading to the creation of a Faculty of Family Planning for advocacy and education as well as to support general reproductive health care. Twenty-five years later, in 2013, there are indications that greater priority in international development will soon be given to sexual health.

\section{PREVENTING INFECTION}

In 1988, 6 years had passed since AIDS had emerged into clinical practice, unfortunately all too often with the label of "the gay plague". There was hope for control of the HIV epidemic either with a vaccine as had been so effective for the eradication of smallpox, or with antimicrobial therapy as for syphilis, since the quarantine of affected individuals was neither politically nor practically feasible. Malcolm Potts emphasised the crucial role of individual behaviour for the control of the HIV epidemic. ${ }^{1}$ Taking a historical view, he felt that the introduction of syphilis to Europe by Columbus's crew had played a role in promoting Puritanism, as the fear of syphilis had resulted in stern punishment for sexual immorality, resulting in profound changes in sexual behaviour that had led to a major decrease in illegitimacy. As family planning was "the branch of medicine with the strongest tradition of prevention", Potts was convinced of its role for HIV control through the promotion of community partnerships and empowerment of individuals for informed choice, instead of "enforced ignorance". Since "coital expression of sex is regulated by law and restricted by religion" and HIV is "moving more rapidly than bureaucracies can react", young people needed special attention as they "always take appalling risks out of ignorance or malice".

The value of widespread adoption of safer sex practices was recognised for the control of HIV in order to complement the central role of mutually faithful sexual relationships, which so often failed. In the consideration of personal anxiety regarding the risk of viral transmission despite the utilisation of barrier methods, John Guillebaud pointed out that monogamy would increasingly become the norm, with non-coital systemic contraception facilitating "fun sex". ${ }^{2}$ During an Eastern Mediterranean cruise, a well-known family planning practitioner was convinced that her fellow middle-aged British passengers believed in monogamy, as represented by an illustration of tenderness between wife and husband on the throne of Tutankhamun. ${ }^{3}$ However, she witnessed the general embarrassment of those Britons regarding sexuality issues such as the presence of gay partners on board the liner and the sight of an "erect penis of a very minor god on the dark side of a sandstone wall". She was impressed by the sensuous architecture of the numerous places of religious worship and also by the fecundity of modern Egypt, with over half the population being under the age of 16 years. $^{3}$

\section{CONTROLLING FERTILITY}

From its origin as birth control, the term coined by Margaret Sanger in 1914, family planning was already perceived by the public as encompassing "the wider area of reproductive health care" and not only limited to contraception, so moralistic attitudes by professionals regarding sensitive issues could have adverse effects on service provision. ${ }^{4}$ Addressing the morality of abortion, David Bromham, later the first Chairman of the Faculty of Family Planning and Reproductive 
Health Care, considered the three interrelated yardsticks of religious philosophy, legislation and public opinion, the last of which he described as being a "nebulous entity". He concluded that there was "more to democracy than public opinion" and besides, "more to morality than sex and more to law than crime". 5 As the old axis of medical ethics was shifting from considerations of sanctity of life and healing to quality of life and relief of suffering, there was a potential challenge for those service providers who did not wish to carry out abortions for reasons of personal conscience. ${ }^{6}$

An evaluation of a service for the provision of postcoital contraception found that almost all women with failure of the techniques proceeded to choose termination of pregnancy. ${ }^{7}$ It was reassuring to learn that the Attorney General was of the opinion that the provision of postcoital contraception, whether hormonal or with the intrauterine contraceptive device, did not contravene the 1967 Abortion Act. ${ }^{8}$

\section{DECLINING PRIORITY}

In 1988, there was dismay in Britain regarding the state of family planning. This situation was most disappointing after the various initiatives of the previous two decades. The driving forces of 1968 had led to a major boost for family planning services, increasing their accessibility, with tangible outcomes such as smaller family size, better maternal health and lower perinatal mortality. Unfortunately, the utterings of continuing support by official authorities had not been accompanied by the allocation of appropriate resources: with preventive services playing second fiddle to curative treatment, family planning services were not sustainable any more and it was anticipated that the deprived and poor would be the most affected. Although well recognised as being among most the most effective services, family planning seemed to be "taking a back seat" with the term being "unmentionable in some prominent quarters", an indication of a return to a "particular Victorian value". ${ }^{9}$ It was most surprising that the 1987 White Paper 'Promoting Better Health' had failed to mention either family planning or contraception in its 65 pages of text. Luckily, British medical professionals were able to draw upon the international 'Health for All' movement to justify resource allocation for family planning which had been included, within maternal and child health, as an essential element in the milestone Declaration of Alma-Ata of the 1978 International Conference on Primary Health Care. ${ }^{9}$

Realising that the problems facing family planning in Britain related to "the lack of an academic body with a specific responsibility for this clinical field and with a strong voice to provide professional support", the President of the Royal College of Obstetricians and Gynaecologists, Sir George Pinker, invited representatives of the Royal College of General
Practitioners, the National Association of Family Planning Doctors (NAFPD) and the Joint Committee on Contraception to a meeting held in November 1987 to set up a Faculty of Family Planning. At the follow-up meeting in January 1988, it was decided that "the fields covered will include general reproductive health care", with incorporation of the NAFPD administration and its Journal into the Faculty. ${ }^{10}$

\section{SEIZING THE OPPORTUNITY}

And now, 25 years on, I still feel that there continues to be great neglect of certain components of sexual and reproductive health in international development, where there is an emphasis on reproductive, as opposed to sexual, rights. Maternal health is recognised as being important, but induced abortion is relatively neglected despite being an extremely important cause of preventable maternal mortality. Similarly, drug therapy for HIV control is prioritised, whereas sexually transmitted infections are relatively ignored in service provision. Finally, much emphasis is placed on activities for young people but their sexuality is not addressed.

Broad involvement of civil society, including religious authorities, is desirable for policy formulation. There was much hope for a change in stance in the teachings of the Catholic Church with the election of Pope Francis in March 2013, with his proven concern for the poor, sick, needy and other vulnerable groups in society, in line with his veneration of Saint Francis of Assisi. However, The Light of Faith, his first encyclical, published in July 2013 just after his first 100 days in office, did not indicate any change in direction from the legacy left by Pope Benedict XVI on issues such as contraception, abortion and same-sex marriage. ${ }^{11}$ It stated that the increasing role of technology-based evidence in the search for truth should be balanced by more emphasis on considerations of faith during the subsequent decision-making, especially for issues pertaining to life. This papal teaching stressed the role of family and faith for the joy of young people. With the track record of Pope Francis for dialogue, intense discussions are likely to continue on those issues.

A possibly brighter 'Light' is the application by the United Nations of international human rights agreements that have the potential to promote sexual rights and to end discriminatory practices regarding sexual orientation and gender identity. ${ }^{12}$ The current discussions to set the agenda during the post-2015 follow-up to the Millennium Development Goals will provide a unique opportunity to prioritise sexual health in international development. In its report of early June 2013, the High-Level Panel of the United Nations emphasised health promotion, disease prevention and the reduction of inequality: it recommended the implementation of the full range of services for operationalising universal sexual and reproductive health and rights, even specifying the special needs of 
lesbian, gay, bisexual and transgender groups. ${ }^{13}$ The challenge during the forthcoming negotiations now consists of overcoming any obstacles to the adoption of the goals that will guide priorities for international development during the coming decades.

\section{Competing interests None.}

Provenance and peer review Not commissioned; internally peer reviewed.

\section{REFERENCES}

1 Potts M. The most presumptuous pox - AIDS and contraception. Br J Fam Plann 1988;13:144-147.

2 Guillebaud J. The 14th Jennifer Hallam Memorial Lecture Present and future trends in contraception. Br J Fam Plann 1988;13(Suppl. 4):2-8.

3 Wilson ESB. Thoughts on returning from abroad. Br J Fam Plann 1988;14:58.

4 Belfield T. Consumer perceptions of family planning. Br J Fam Plann 1988;13(Suppl. 4):46-53.

5 Bromham DR. The law, public opinion and reproductive medicine. Br J Fam Plann 1988;14:39-40.

6 Sims PF, de S Cameron NM. New medicine for old - the demise of the Hippocratic tradition. Br J Fam Plann 1988;14:96-97.
7 Friedman EHI, Rowley DEM. Post-coital contraception - a two-year evaluation of a service. Br J Fam Plann 1988;13:139-144.

8 Orr CJB. Some medicolegal problems associated with contraception. Br J Fam Plann 1988;13(Suppl. 4): $35-40$.

9 McEwen J. Health for all: but where has all the family planning gone? Br J Fam Plann 1988;14:1-2.

10 Anonymous. Minutes of AGM. Br J Fam Plann 1988;14:106-108.

11 Pope Francis. Lumen fidei. Encyclical letter of the Supreme Pontiff to the bishops, priests and deacons, consecrated persons and the lay faithful on faith. Paragraphs 11, 25, 34, 52. Vatican City, Rome, Italy: Vatican Press, 2013.

12 United Nations. Discriminatory Laws and Practices and Acts of Violence Against Individuals Based on their Sexual Orientation and Gender Identity. Report of the United Nations High Commissioner for Human Rights. Document A/HRC/19/41. United Nations General Assembly. New York, NY: United Nations, 2011.

13 United Nations. A New Global Partnership: Eradicate Poverty and Transform Economies Through Sustainable Development. The Report of the High-Level Panel of Eminent Persons on the Post-2015 Development Agenda. New York, NY: United Nations, 2013:17, 30, 38-39, 62-63. 